\title{
1 Land use, land use change and soil 2 carbon sequestration in the St. Johns 3 River Basin, Florida, USA
}

4 C. Wade Ross ${ }^{a}$, Sabine Grunwald ${ }^{a^{*}}$, David Brenton Myers ${ }^{a, b}$, Xiong Xiong ${ }^{a}$

$5{ }^{a}$ Soil and Water Science Department, University of Florida, 2181 McCarty Hall, PO Box 110290,

6 Gainesville, FL 32611, USA

$7{ }^{\mathrm{b}}$ Division of Plant Sciences, University of Missouri, 214 Waters Hall, 1-41 Agriculture Building, Columbia,

8 MO 65211, USA

$9 \quad *$ Corresponding author: S. Grunwald, 1 352-294-3145, sabgru@ufl.edu 


\section{Abstract}

Land use change is widely recognized as a net source of greenhouse gas emissions at the global scale. Most of these emissions are attributed to losses from aboveground terrestrial pools such as deforestation. However, much less is known about the effects of land use change on soil carbon pools at

14 regional scales. To address this problem, relationships between soil organic carbon (SOC), land use / 15 land cover (LULC) classes, and LULC change were investigated at the regional scale. A legacy soil survey 16 was used in conjunction with a new, contemporary sampling campaign to determine SOC change though

17 time. Together, the two datasets cover an approximate 40-year time period (1965 to 2009). The greatest densities of SOC were documented in wetland classes. Specifically, soils of Hardwood Swamp, Cypress Swamp, and Mixed Wetland Forest contained 9.8, 9.5, and $7.8 \mathrm{~g} \mathrm{C} \mathrm{m}^{-2}$. In regards to absolute storage, or SOC stocks, Hardwood Swamp, Pineland, and Urban ranked highest and contained 14.4, 13.3, and 9.9 Tg

22 field scale. At the regional scale, median SOC increased by $16.9 \mathrm{~g} \mathrm{C} \mathrm{m}^{-2} \mathrm{yr}^{-1}$. Urbanization of natural

23 landscapes resulted in the largest rate of sequestration, which increased SOC by $37.1 \mathrm{~g} \mathrm{C} \mathrm{m}^{-2} \mathrm{yr}^{-1}$. The 24 largest losses were documented in LULC classes converted from Improved Pasture to Rangeland, which decreased SOC by $8.5 \mathrm{~g} \mathrm{~m}^{-2} \mathrm{yr}^{-1}$. 


\section{Introduction}

Anthropogenic activities have led to a dramatic increase in the concentration of atmospheric carbon-dioxide $\left(\mathrm{CO}_{2}\right)$ and other greenhouse gases (GHGs), which in turn has increased radiative forcing and contributed to global warming (Prentice et al., 2001; Shine and Forster, 1999). As a result, many countries have begun developing policies to mitigate anthropogenically induced global warming and subsequent changes to climate (Fischer and Newell, 2008). One such strategy aims to mitigate anthropogenic emissions by increasing the carbon sink and storage capacity of the terrestrial biosphere through proper land use management (Lal, 2014; Schimel, 1995). However, the amount and rate at which carbon can be transferred from the atmosphere to the terrestrial biosphere is not yet fully understood. Despite this uncertainty, it is clear that the terrestrial biosphere plays a critical role in the carbon cycle by actively exchanging carbon with the atmosphere, serving as both a sink and a source for 39 carbon.

Globally, the terrestrial biosphere serves as a net carbon sink (- $1.6 \mathrm{Pg} \mathrm{C} \mathrm{yr}^{-1}$ ) (Ciais et al., 2014).

41 However, emissions from land use change represent a significant source of carbon (0.9 Pg C $\left.\mathrm{yr}^{-1}\right)$,

42 accounting for approximately $17 \%$ of anthropogenic GHG emissions (Ciais et al., 2014). Since the 1980's,

43 the majority of these emissions have been attributed to deforestation in the tropics and the sub-tropics,

44 a trend that is expected to continue in order to keep up with the growing demand for food as the

45 world's population is expected to surpass 9 billion by mid-century (Godfray et al., 2010). This is an

46 important consideration, as tropical and subtropical ecosystems have been estimated to store more

47 carbon in vegetation and soils (combined) than any other ecosystem (Eglin et al., 2010). The majority of

48 this carbon is stored below ground as soil organic carbon (SOC), with turnover times ranging from years 49 to thousands of years (Parton et al., 1987). In undisturbed conditions, the soil carbon pool is considered to be in a state of equilibrium as 51 sources and sinks balance one another over relatively short time scales (Fearnside and Barbosa, 1998). 
52 Across large geographic regions, this equilibrium depends primarily on vegetation type and productivity,

53 which in turn is governed by climate and the soil forming factors first described by Dokuchaev (Glinka,

54 1927) and popularized by Jenny (1941). Additional factors, such as genoform (McBratney et al., 2003)

55 and anthropogenic activities (Grunwald et al., 2011b) also influence SOC. Land use change, which often

56 results in changes to land cover, has the potential to disrupt this equilibrium, causing soils to act as a

57 source or sink of carbon until a new equilibrium is reached (Watson et al., 2000).

Identifying relationships between SOC, land use and land cover (LULC) can provide important

59 information for predicting the effects of LULC change on SOC pools. Additionally, this information can be used for developing policy and management guidelines that mitigate anthropogenic GHG emissions. The

61 tropics and sub-tropics represent one of the largest areas of uncertainty in regards to carbon dynamics,

62 as it is not yet clear if these soils serve as a net sink or source for carbon (Baker et al., 2004; Clark, 2004).

63 The state of Florida provides an excellent opportunity to study these relationships due to its unique

64 environmental, climatic, and socio-economic conditions. Florida ranks highest in terms of SOC storage

65 among conterminous U.S. (Guo et al., 2006). Much of this carbon is at risk to being transferred to the

66 atmosphere via deforestation, land clearing, and other forms of LULC change driven largely by an

67 increasing population, which is expected to increase $80 \%$ by 2030 , surpassing 28 million people (U. S.

68 Census Bureau, 2005).

Considering the amount of carbon stored in Florida's soils in addition to its risk of being

70 transferred to the atmosphere via LULC change, it is imperative to gain a better understanding of

71 relationships between soils and LULC, as well as the effects of LULC change on soil carbon pools in this

72 region. The primary objectives of this study were to i) identify relationships between SOC and LULC

73 classes across a large subtropical region in Florida based on contemporary soil survey and ii) assess the

74 effects of LULC change on SOC dynamics over a 40-year time period by utilizing legacy data. 


\section{Materials and Methods}

\subsection{Study Area}

This study was conducted in the Lower, Middle and Upper St. Johns River Basins as well as the Ocklawaha River Basin of Florida, located between latitudes $30.48^{\circ}$ to $27.51^{\circ} \mathrm{N}$ and longitudes $-82.43^{\circ}$ to $-80.74^{\circ} \mathrm{W}$ (Figure 1). The region has a subtropical climate, receiving approximately $1,224 \mathrm{~mm}$ of precipitation annually with a mean annual temperature of $20.5^{\circ} \mathrm{C}$ (National Climatic Data Center, 2011). Elevation within the study area is flat to mildly undulating and ranges from below sea level (-1 $\mathrm{m})$ to 95 m above sea level (United States Geological Survey, 2006). Soil erosion and deposition are relatively minor due to the topography and therefore have negligible effects on soil formation and carbon dynamics. The soils in the study area were formed in sandy to loamy marine derived parent material with sand as the dominant particle size fraction. Dominant soils include Spodosols (31\%), Entisols (24\%) and Alfisols (11\%) (Table 1 and Figure 2) (Soil Survey Staff, 2008), with Pineland (16\%), Urban (12\%), and Rangeland (10\%) making up the major LULC classes (Table 2) (Stys et al., 2004).

\subsection{Data sources}

Legacy data was used in conjunction with a modern soil sampling campaign in order to assess soil carbon dynamics through time. Together, the two data sources cover an approximate 40-year time period (1965-2009). The legacy data, hereafter referred to as Dataset 1 (DS1), is a horizon based subset ( $N=403$ ) from the "Florida Soil Characterization Dataset" (FSCD) (G. M. Vasques et al., 2010). Soil samples were collected from 1965 - 2006. Walkley-Black (WB) and loss-on-ignition (LOI) were used to measure soil organic matter (SOM) for mineral and organic soils, respectively. The current data, hereafter referred to as Dataset 2 (DS2), is a subset ( $N=304)$ from the "Rapid Assessment and Trajectory Modeling of Changes in Soil Carbon across a Southeastern Landscape" and sampled between 2008 2009 (Grunwald et al., 2011a). A fixed depth (0-20 cm), stratified-random sampling design was 
implemented in order to make inferences regarding relationships between SOC and vegetation. Samples were stratified according to soil suborder and dominant land cover classes; approximately half of DS2 was designed to be a paired re-sampling of DS1, allowing SOC dynamics to be assessed. The pairwise comparison also allowed LULC to be tracked through time. Total carbon (TC) was measured as carbondioxide $\left(\mathrm{CO}_{2}\right)$ evolution using $50-500 \mathrm{mg}$ of ball milled soil samples combusted at $900{ }^{\circ} \mathrm{C}$. Inorganic carbon (IC) was derived by reacting $20-250 \mathrm{mg}$ of ball milled soil with $42.5 \%$ phosphoric acid $\left(\mathrm{H}_{3} \mathrm{PO}_{4}\right)$ in the gas analyzer at $200^{\circ} \mathrm{C}$. The difference between TC and IC was used to derive SOC. It should be noted that IC was negligible in most soil samples, which is not surprising considering the acidic nature of soils in this region due to high annual precipitation rates.

In order to make direct comparisons between the two datasets, Florida specific pedo-transfer functions (PTFs) were developed by performing dry-combustion analysis on archived samples from DS1 to convert measurements of SOM to SOC. Specifically, separate PTFs were developed to convert SOM measured using WB for mineral soils as well as SOM measured using LOI for organic soils. The PTFs for mineral and organic soils resulted in an $\mathrm{R}^{2}$ of 0.92 and 0.998 , respectively. The details of the PTF have previously been published in Ross et al. (2013). Additionally, the horizon based sampling scheme of DS1 was re-constructed to $20 \mathrm{~cm}$ profile depths to allow for direct comparisons with DS2. Bulk density ( $\left.\mathrm{B}_{\mathrm{d}}\right)$ measurements were available for both datasets and used to derive SOC density ( $\mathrm{g} \mathrm{C} \mathrm{m}^{-2}$ ). SOC stock ( $\mathrm{Tg}$ C) was estimated for each LULC class by using density measurements and the total area of LULC classes. To account for the temporal variation in which samples were collected during each campaign, SOC change was calculated on a "per year basis" for each pairwise comparison.

\subsection{Land use / Land cover classification}

Historical LULC classes needed to be re-constructed, as the legacy data was not stratified according to LULC classes. However, field crews recorded notes describing the vegetation at sample locations. These notes were used in combination with historical aerial photographs as well as historical 
122 imagery provided by the Google Earth Time Machine (Lisle, 2006) to re-construct historical land cover

123 classes. Remote sensing data processed by the Florida Fish and Wildlife Conservation Commission (FWC)

124 (Stys et al., 2004) was used to stratify DS2 according to LULC classes. This was the most complete and

125 detailed LULC data available for the current soil survey. Additionally, LULC was verified by

126 groundtruthing in order to avoid misclassification errors common for remote sensing (Congalton, 1991).

127 To increase the statistical power of the stratified design, LULC classes were aggregated (Table A.1) from

128 the lowest, most specific classes to higher, more generalized classes while preserving the hierarchical

129 classification scheme developed by FWC. For example, Xeric Oak Scrub, Sand Pine Scrub, and Sandhill

130 were aggregated to the higher, less differentiating class of Xeric Uplands.

\subsection{Data analysis}

Due to the non-normal distribution of residuals and uneven class sizes, the Kruskal-Wallis one-

way analysis of variance (ANOVA) was employed to determine if SOC was significantly different between

134 LULC classes. Post-hoc multiple comparisons were performed to identify which classes were significantly

135 different. The Wilcoxon signed-rank test was used with the collocated samples (pairwise comparisons)

136 to determine if significant differences existed between DS1 and DS2. Additionally, the Mann-Whitney (or

137 Mann-Whitney U) test was extended to the entire population (paired and unpaired samples) to

138 determine if the distributions of both populations were equal.

\section{3. Results and Discussion}

\subsection{Current soil organic carbon and soil type}

Measured SOC was highly variable for both DS1 and DS2 (Figure 3 and Figure 4). The datasets

142 had similar distributions, however, DS1 was more right skewed due to some extreme values in the upper 143 range. Soil organic carbon density ranged from 0.4 to $59.7 \mathrm{~kg} \mathrm{C} \mathrm{m}^{-2}$ with a median of $2.6 \mathrm{~kg} \mathrm{C} \mathrm{m}^{-2}$ (DS1) 
144 145

146

147

and 0.5 to $24.6 \mathrm{~kg} \mathrm{C} \mathrm{m}^{-2}$ with a median of $3.3 \mathrm{~kg} \mathrm{C} \mathrm{m}^{-2}$ (DS2). For both datasets, Histosols contained the greatest densities of SOC, while the smallest densities were observed in Entisols (Table 1). Although SOC varied substantially between suborders, statistical differences were largely indistinguishable. This has been attributed to the high variance of SOC found within and between soil classes (Ahn et al., 2009).

\subsection{Current soil organic carbon and land use/ land cover}

Soil organic carbon was highly heterogeneous within and between land cover classes as well (Figure 5), with median $\mathrm{SOC}$ density $\left(\mathrm{g} \mathrm{C} \mathrm{m}^{-2}\right)$ decreasing in the following order: Hardwood Swamp > Cypress Swamp $>$ Mixed Wetland Forest $>$ Freshwater Marsh/Wet Prairie $>$ Shrub Swamp $>$ Urban $>$ Improved Pasture $>$ Pineland $>$ Mesic Upland Forest $>$ Rangeland $>$ Citrus $>$ Crop $>$ Xeric Upland Forests (Table 2). Although statistically significant SOC differences between LULC classes were largely indistinguishable, SOC varied substantially both within and between LULC classes as shown in Table 3 and Figure 5. These findings highlight the relationship between soil water, LULC, and SOC. In a statewide study, Xiong et al. (2014a) used Boruta all-relevant variable selection to determine which variables, out of 210 , were strongly correlated with SOC. They reported LULC and soil water ranked highest and $4^{\text {th }}$ highest, respectively, out of 43 "all-relevant" variables. In regards to total storage, or SOC stocks (Tg C), Hardwood Swamp, Pineland, and Urban classes ranked highest, containing 14.4, 13.3, and 9.9 Tg C, respectively. In contrast, Citrus, Crop, and Xeric Upland Forest ranked lowest, containing 1.0, 1.7, and $2.8 \mathrm{Tg}$ C, respectively.

\subsubsection{Wetland soils}

The highest SOC densities were documented in wetland classes (Table 2). When grouped together, wetlands accounted for nearly half $(42.9 \mathrm{Tg} \mathrm{C})$ of the regions total SOC stock, which is substantial considering they comprised just one-quarter of the land area. Hardwood Swamp, the most prominent wetland class, ranked highest in both SOC density and stock, accounting for nearly $16 \%$ (14.4 
$167 \mathrm{Tg}$ ) of the regions carbon stock. This class predominantly consisted of pure stands of hardwoods or

168 mixtures of hardwoods and cypress where hardwoods achieved dominance. These wetland-adapted

169 trees occur throughout the state and are found at shallow, stagnant depressions or at the base of

170 sandhills where seepage maintains hydric conditions throughout the year. These conditions, combined

171 with long growing seasons, high average temperatures, and ample supply of water contributes to the

172 high carbon density that characterizes this and other wetland classes in the region, and helps explain

173 why Florida ranks highest among all conterminous US states in terms of SOC storage (Guo et al., 2006;

174 Xiong et al., 2014b). Although no significant differences were observed among wetland classes in

175 regards to SOC, a great deal of variance exists between classes as illustrated in Figure 5.

\section{$176 \quad 3.2 .2 \quad$ Urban soils}

Urban soils ranked highest in terms of median SOC density for non-wetland classes and $3^{\text {rd }}$

178 highest in terms of total SOC stock across the region. Although Urban consisted of both residential and

179 commercial land uses with a variety of vegetation and soil types, the majority of sites were surveyed in

180 residential neighborhoods that consisted of Entisols (43\%) planted with turf grass (Stenotaphrum

181 secundatum). Additionally, many of these lawns appeared to be irrigated and fertilized regularly in order

182 to maintain pristine lawn conditions as required by homeowner associations. To highlight differences

183 between Urban and non-urban soils, a subset of the dominant Urban soil suborder (Psamments) was

184 compared to the entire region-wide population of Psamments. This comparison revealed that the

185 median density of SOC in Urban Psamments was $2.9 \mathrm{~kg} \mathrm{~m}^{-2}$, or $32 \%$ greater than the entire population of

186 Psamments for all land cover classes. These findings can be attributed to differences in both land use

187 and land cover. Land management, such as fertilization and irrigation of lawns, have been found to have

188 favorable effects on SOC storage (Conant et al., 2001). Ecophysiological properties, such as higher

189 proportions of below ground biomass characteristic of grass, allows for a greater contribution of

190 belowground inputs from roots, which decomposes slower and contributes more efficiently to SOC 
191 storage in top-soils (Cairns et al., 1997). Pouyat et al. (2002) also documented high densities of SOC in

192 urban soils and found that low density residential and institutional land uses had 44 and $38 \%$ greater

193 densities of SOC compared to industrial land uses.

$194 \quad 3.2 .3 \quad$ Agricultural soils

195 Agricultural lands, which include Improved Pasture, Rangeland, Crop, Citrus, and Other

196 Agriculture, occupy nearly one-quarter (24\%) of the regions land area and account for approximately

$19718 \%(16.4 \mathrm{Tg})$ of total SOC stock. Improved Pasture ranked below Urban in terms of median SOC density

198 (Table 2). Sites in this class were predominantly seeded with Bahia grass (Paspalum notatum) and

199 surveyed on 6 distinct soil suborders with varying soil moisture regimes and drainage classes. In

200 contrast, rangeland sites, which are often observed on the same soils and in some cases adjacent to

201 Improved Pasture, had lower SOC density, although not significantly different (Table 3). In this study,

202 Improved Pasture was distinguished from Rangeland primarily due to land management, which helps

203 explain the discrepancy in SOC between these two LULC classes. Typical land management practices for

204 Improved Pasture in this region consisted of planting improved seed stocks, irrigation, grazing

205 management, and fertilization, which have been shown to increase SOC sequestration in other regions

206 of Florida and the Southeast US (Silveira et al., 2012). The introduction of irrigation alone has been

207 found to increase SOC on average by $5.4 \%$ annually across a wide variety of climates (Conant et al.,

208 2001). This cause and effect relationship is most pronounced in the upper $10 \mathrm{~cm}$ soil profile of managed

209 grasslands, where soil C sequestration rates are greatest (Conant et al., 2001), and suggests grassland

210 soils may act as a significant $\mathrm{C}$ sink as a result of land management. The lowest densities of SOC were

211 measured in Citrus and Crop, accounting for 3\% (2.7 Tg) of the regions total SOC stock. These findings

212 reveal the relatively low SOC storage in row and crop soils of this region. 


\subsubsection{Forest soils}

Forested (non-wetland) classes accounted for $27 \%\left(6,081 \mathrm{~km}^{-2}\right)$ of the land area and $23 \%(20.1$ $\mathrm{Tg}$ ) of the regions SOC stock. Soil organic carbon density was highest in Pineland sites, followed by Mesic Upland Forest, and Xeric Upland Forest. Due to the high density of SOC and large areal extent, Pineland soils store more carbon than all other LULC classes except for Hardwood Swamp. Pinelands were sampled on 8 soil suborders ranging from well-drained upland soils, such as Psamments, to poorly drained soils such as Aquods. The variability of SOC density between these soil suborders was pronounced, with Psamments - Pineland soils containing $1.1 \mathrm{~kg} \mathrm{C} \mathrm{m}^{-2}$, as opposed to $3.4 \mathrm{~kg} \mathrm{C} \mathrm{m}$ observed in Pineland - Aquods. Land management varied as well, consisting of little to no management on native stands to highly managed, genetically improved commercial stands that typically receive nutrient inputs, competition control, and other management practices, which have been shown to increase productivity and carbon sequestration in southern pine (Maier et al., 2004). Improved land management has important economic implications as well, as Pinelands are an important commodity in the region as well as the entire Southeastern U.S. Southern pine forest not only store large amounts of SOC, but also account for $60 \%$ of the U.S. timber production and sequester as much as $210 \mathrm{Tg} \mathrm{C}$ annually, which is equivalent to $12 \%$ of the U.S. carbon emissions from fossil fuels (Johnsen et al., 2001; Wear et al., 2002). These findings highlight the importance of Pinelands in regards to carbon sequestration and storage in this region.

Although the extent of Mesic and Xeric Upland Forests were similar across the region, total SOC stock was 35\% greater in Mesic Upland Forest. This is largely due to the higher SOC density observed in Mesic Upland Forest, which can be explained by landscape position and subsequent soil moisture status. For example, Xeric Upland Forests occurred predominantly (80\%) on Psamments of well-drained sandhill communities. In contrast, Mesic Upland Forest soils were surveyed predominantly in aquic soil moisture regimes. 


\subsection{Soil organic carbon dynamics}

The use of legacy data allowed SOC dynamics to be investigated over an approximate 40 year time period. Although SOC change was highly variable between LULC classes during this time period (Figures 6 and 7), median SOC increased by $16.9 \mathrm{~g} \mathrm{~m}^{-2} \mathrm{yr}^{-1}$ at collocated sites. This was confirmed by the Mann-Whitney-Wilcoxon test, which indicated the median density of SOC differed significantly between the two datasets $(P<0.05)$. The Mann-Whitney test was used to test the entire population (paired and un-paired samples), which yielded the same results; median SOC between the two datasets differed at the 0.05 level of significance. These findings suggest that soils of the region served as a net carbon sink during the studies time period. In a similar study, Xiong et al. (2014b) concluded that SOC increased across the entire state of Florida during the same time period.

Generally speaking, SOC is governed primarily by climate, soil genoform and LULC (Feller and Beare, 1997; Vasques et al., 2012). Because SOC is typically in a state of equilibrium in undisturbed conditions, a logical explanation accounting for the observed increase in SOC would be that one or more events perturbed the carbon cycle in this region. Assuming the soil genoform has not changed during this study's time frame, changes in climate and LULC may explain the observed increase in SOC. Longterm monthly climate data was analyzed in order to determine if changes in climate had any substantial impact on SOC dynamics. No significant trends were observed in long-term precipitation and temperature data in the region according to the Mann-Kendall test, suggesting these climate properties had little or no effect on SOC change during this studies time period.

Other studies conducted in Florida also reported that temperature and precipitation were weakly correlated with SOC at the regional scale ( Vasques et al., 2010a, 2010b; Xiong et al., 2014a). Although these climate variables did not have a substantial effect on SOC change, increased NPP, which correlates well with temperature and precipitation at the global scale (Del Grosso et al., 2008), may have increased indirectly from the $\mathrm{CO}_{2}$ fertilization effect (Allen et al., 1996). Increased productivity and sink 
261 capacity, known as the "residual terrestrial uptake", helps explain the $\sim 2 \mathrm{Gt}$ C $\mathrm{yr}^{-1}$ discrepancy that

262 remains in estimates of global carbon budgets (Watson et al., 2000). Overall, SOC sequestration

263 followed a positive trend at the regional scale, however, it varied highly both within and between LULC

264 classes (Figure 4 and Figure 5), which was largely attributed to LULC change. Land use / land cover

265 change was documented at 35\% of the collocated sites, including Coastal Upland, Pasture/Other

266 Agriculture, Pineland, Rangeland, Row/Field Crop, Urban, and Xeric Upland Forest.

267

268

269

270

271

272

273

274

275

276

277

278

279

280

281

282

283

284

\subsubsection{Urbanization}

Urbanization accounted for nearly half (44\%) of the LULC change at collocated sites across the region. Soil organic carbon increased $36.8 \mathrm{~g} \mathrm{~m}^{-2} \mathrm{yr}^{-1}$ when averaged across all urbanized landscapes. One-hundred percent of Coastal Upland sites were converted to Urban landscapes between sampling periods and SOC increased by $37.1 \mathrm{~g} \mathrm{~m}^{-2} \mathrm{yr}^{-1}$ on average. This also highlights development along the regions coastal areas. Nearly one-quarter (22\%) of collocated Rangeland sites were urbanized, with median SOC increasing by $8.6 \mathrm{~g} \mathrm{~m}^{-2} \mathrm{yr}^{-1}$ on average. Urbanization of forested sites resulted in mixed findings. For example, SOC of forested sites (Xeric and Mesic Upland forests combined) increased $23.7 \mathrm{~g}$ $\mathrm{m}^{-2} \mathrm{yr}^{-1}$ on average when grouped together. However, when looking at these forested sites individually, SOC decreased by $6.7 \mathrm{~g} \mathrm{~m}^{-2} \mathrm{yr}^{-1}$ on average after urbanization of Mesic Upland. Conversely, SOC increased by $46.5 \mathrm{~g} \mathrm{~m}^{-2} \mathrm{yr}^{-1}$ on average in Xeric Upland Forest after conversion to Urban.

Carbon sequestration in soils of urbanized lands was explained, at least in part, by changes in both land use and land cover. For example, although Urban classes consisted of both residential and commercial land uses with a variety of vegetation types, the majority of sites were surveyed in lawns of residential neighborhoods seeded with St. Augustine's grass (Stenotaphrum secundatum). As discussed above, the unique ecophysiological properties of grasses allows for a greater contribution of belowground inputs from roots, which decomposes slower and contributes more efficiently to SOC storage in the topsoil (Cairns et al., 1997). Additionally, many of the residential lawns were irrigated and 
fertilized on a regular basis, as required by homeowner associations. This combination of planted turf grass combined with increased nutrient and water inputs favor SOC sequestration in the upper soil profile. The disagreement in the direction of SOC sequestration of urbanized forested sites (Mesic and Xeric Upland Forests) is difficult to interpret. Considering that median SOC was higher in Urban, a logical expectation is that conversion of these forested systems to Urban would result in SOC gains for both classes. However, increased SOC was only documented in Xeric Upland Forests. It should be noted, however, that the variance of urbanized Mesic Upland Forest sites was greater than both the mean and median. As such, drawing hard conclusions from these results is not possible.

\subsubsection{Rangeland}

Conversion to Rangeland occurred at $21 \%$ of collocated sites in the region. Only two classes were converted to Rangeland during this studies time period, including Pineland and Pasture/Other Agriculture. Conversion of Pineland to Rangeland increased SOC by $5.4 \mathrm{~g} \mathrm{~m}^{-2} \mathrm{yr}^{-1}$, while conversion of Pasture/Other agriculture resulted in SOC loss of $8.5 \mathrm{~g} \mathrm{~m}^{-2} \mathrm{yr}^{-1}$. In a similar study, Post and Kwon (2000) found that sites switching from forests to unimproved pasture, which resembles Rangeland in this region, lost $17.4 \mathrm{~g} \mathrm{C} \mathrm{m}^{-2} \mathrm{yr}^{-1}$. One possible explanation to this discrepancy could be due to the time frame in which SOC was surveyed after LULC conversion. In this study, the majority of sites converted from Pineland to Rangeland were surveyed relatively soon (months to years) after conversion. In most cases given enough time, equilibrium pools may decline under prolonged Rangeland conditions.

Sixty-seven percent of sites originally identified as Rangeland experienced LULC change. These sites were converted to Pasture/Other Agriculture, Pineland, Row/Field Crop, and Urban LULC classes. Median SOC increased in all cases, with conversion to Pasture/Other Agriculture resulting in the largest increase at $20.1 \mathrm{~g} \mathrm{C} \mathrm{m}^{-2} \mathrm{yr}^{-1}$ on average. However, the contrary (Improved Pasture to Rangeland) did not result in any clear trends as the variance was too high. It is worth noting that sites remaining in 
class in this study. In many instances Rangeland was the closest or best-fit LULC class. It included a

310 variety of vegetation types and land uses, such as pure range for cattle, shrub, and/or scrubland, as well

311 as sites in land-use transition.

Interest in sustaining agricultural soils has gained international attention in recent years as

researchers and policy makers have begun to recognize global existential challenges, all of which directly documented in tropical soils as a result of agricultural practices (Dechert et al., 2004; Lumbanraja et al., 1998). Conversely, tropical soils recovering from degraded states have been estimated to sequester as much as $553 \mathrm{Tg} \mathrm{C} \mathrm{yr}^{-1}$ (Lugo and Brown, 1993). And yet some studies have documented both an increase and decrease in tropical soil carbon through time (Minasny et al., 2011). Losses in the range of $20-40 \%$ SOC are not uncommon in agricultural soils (Davidson and Ackerman, 1993) and reductions as high as 50\% are possible (Post and Kwon, 2000). Other studies have found that SOC losses may be reversed by returning land to native conditions or through use of best management practices that aim to reduce SOC

322 mineralization (Guo and Gifford, 2002). Indeed, SOC has been documented to increase upon conversion

323 from forests to pasture (8\%), crop to pasture (19\%), and crop to secondary forest (53\%) (Guo and

324 Gifford, 2002). These studies highlight the uncertainties associated with LULC change, a trend that is 325 expected to continue in order to keep up with the growing demand for food as the world's population is 326 expected to surpass 9 billion by mid-century (Godfray et al., 2010). Although findings from this study 327 reveal the relatively low status of SOC in agricultural soils of this region, long-term effects from 328 agricultural practices, such as conventional tillage, could not be evaluated, as LULC change in soils of $329 \mathrm{row} /$ field crop did not occur at collocated sites. Therefore, the low SOC status of agricultural soils in this 330 region could not be linked to agricultural practices, as many of these agricultural lands occurred on soils with inherently low nutrient and SOC status. While a comparison of differences between SOC of 
agricultural soils and native soils of the same taxonomic class would shed light on the effects of agricultural practices in the region, it was not the main scope of this project.

\section{Conclusions}

Results from this study reveal the highly heterogeneous nature of SOC within LULC classes as well as soil suborders within a large subtropical region of Florida. This variability can be explained in part by environmental factors, such as landscape position, soil moisture, and vegetation type, which can impact the quantity and quality of organic inputs. Even within a given LULC class, variability exists in terms of genoform, soil moisture, soil texture, and other factors, which are difficult, if not impossible to quantify. The sum of this variance helps explain SOC variance, both within and between soil and LULC classes.

The lowest SOC stocks were documented in Crop (1.7 Tg C) and Citrus (1.0 Tg C), which predominantly occurred on Entisols. Conversely, the largest SOC stocks were documented in Hardwood Swamp (14.4 Tg C), followed by Pineland (13.3 $\mathrm{Tg} C$ ) and then Urban (9.9 $\mathrm{Tg} C$ ) covering 6.8, 15.7, and $12 \%$ of the study region, respectively. When grouped together, wetlands accounted for nearly half (42.9 $\mathrm{Tg} \mathrm{C}$ ) of the regions total SOC stock, highlighting the importance of wetlands in regards to carbon storage and mitigation efforts. As such, it is recommended that these wetlands be preserved in order to maintain the ecosystem services they provide.

Furthermore, the use of legacy data in combination with a modern soil sampling campaign provided an opportunity to assess the overall trend of SOC dynamics over an approximate 40 year time period. Although SOC change was highly variable, the overall trend was positive at the regional scale, and median SOC increased by $16.9 \mathrm{~g} \mathrm{~m}^{-2} \mathrm{yr}^{-1}$ across all collocated sites. These gains were largely attributed to LULC change in addition to environmental factors, albeit to a lesser extent. Urbanization was the most dominant form of LULC change across the collocated study sites, and median SOC density 
355 increased by $36.8 \mathrm{~g} \mathrm{~m}^{-2} \mathrm{yr}^{-1}$ in these urbanized landscapes. However, it should be noted that SOC gains in 356 urbanized soils were primarily attributed to the irrigation and fertilization of residential lawns. Although 357 these practices are favorable for soil carbon sequestration, the gains come at the cost of increased 358 water use and eutrophication of surface waters, which often lead to harmful algal blooms (Heisler et al., 359 2008). Additionally, long-term climate data was investigated for trends to help further explain the 360 region-wide increase in SOC. Although no clear trends in precipitation and temperature data were 361 present, the concentration of atmospheric $\mathrm{CO}_{2}$ has increased $21 \%$ during this studies time period. This 362 " $\mathrm{CO}_{2}$ fertilization effect" might partially explain the positive trend in SOC sequestration at the regional 363 scale. These findings provide new insight into relationships between LULC, LULC change, and SOC 364 dynamics in the St. Johns River Basin based on empirical observations over an approximate 40-year time 365 period. 


\section{Acknowledgements}

We thank the United States Department of Agriculture- Cooperative State Research, Education,

369 and Extension Services-National Research Initiative for providing funding for this project, which is

370 officially referred to as "Rapid Assessment and Trajectory Modeling of Changes in Soil Carbon across a

371 Southeastern Landscape" (USDA-CSREES-NRI grant award \#2007-35107-18368, note: CSREES-NRI was

372 renamed to Agricultural and Food Research Initiative-National Institute of Food and Agriculture). We

373 thank the Florida Department of Transportation for funding the Florida Soil Characterization Project,

374 formally referred to as "Soil and Environmental GIS Data to Support ETDM" (\#722184112), which was

375 jointly conducted by the Natural Resources Conservation Service and Soil and Water Science

376 Department, University of Florida. We also thank Elena Azuaje, Betty Cao, Nick Comerford, Pasicha

377 Chaikaew, Willie Harris, Lisa Stanley, and Aja Stoppe for their role in this study. 
379 Table 1. Descriptive statistics for soil organic carbon by soil suborders using Dataset 2

\begin{tabular}{llllllll}
\hline Soil type & Area & Coverage & Minimum & Mean & Median & Maximum & Standard deviation \\
\hline & $\left(\mathrm{km}^{2}\right)$ & $(\%)$ & $\left(\mathrm{kg} \mathrm{C} \mathrm{m}^{-2}\right)$ & $\left(\mathrm{kg} \mathrm{C} \mathrm{m}^{-2}\right)$ & $\left(\mathrm{kg} \mathrm{C} \mathrm{m}^{-2}\right)$ & $\left(\mathrm{kg} \mathrm{C} \mathrm{m}^{-2}\right)$ & $\left(\mathrm{kg} \mathrm{C} \mathrm{m}^{-2}\right)$ \\
\hline Saprists & 1,655 & 7.4 & 4.7 & 12 & 11.3 & 24.6 & 5.4 \\
Aquolls & 994 & 4.5 & 4.2 & 9.8 & 10.1 & 13.5 & 2.7 \\
Aquepts & 626 & 2.8 & 6.3 & 9.4 & 9.4 & 12.4 & 4.3 \\
Arents & 111 & 0.5 & 5.1 & 5.3 & 5.3 & 5.4 & 0.3 \\
Aquents & 719 & 3.2 & 1.8 & 6.4 & 4.9 & 14.1 & 4 \\
Aqualfs & 2,315 & 10.4 & 1.3 & 5 & 4 & 15.3 & 3.1 \\
Aquods & 5,611 & 25.2 & 1.2 & 4.2 & 3.6 & 12 & 2.5 \\
Aquults & 480 & 2.2 & 1.9 & 5.1 & 3.1 & 17.6 & 5.6 \\
Udults & 902 & 4.1 & 1.4 & 3.2 & 2.6 & 8.8 & 1.5 \\
Orthods & 833 & 3.7 & 1.3 & 3.1 & 2.5 & 7 & 1.9 \\
Psamments & 4,044 & 18.2 & 0.5 & 2.2 & 2.1 & 4.5 & 1 \\
Udalfs & 31 & 0.1 & 1.3 & 2.4 & 2.1 & 5.1 & 1.2 \\
Not sampled* & 3,948 & 17.7 & - & - & - & - & - \\
\hline
\end{tabular}


Table 2. Land use / land cover distribution and measured soil organic carbon $(0-20 \mathrm{~cm})$

\begin{tabular}{|c|c|c|c|c|c|c|}
\hline Land use / land cover classes ${ }^{2}$ & Area & Coverage & Mean & Median & $\begin{array}{l}\text { Standard } \\
\text { Deviation }\end{array}$ & $\begin{array}{l}\text { Total } \\
\text { Stock }\end{array}$ \\
\hline & $\left(\mathrm{km}^{2}\right)$ & $(\%)$ & $\left(\mathrm{kg} \mathrm{C} \mathrm{m}^{-2}\right)$ & $\left(\mathrm{kg} \mathrm{C} \mathrm{m}^{-2}\right)$ & $\left(\mathrm{kg} \mathrm{C} \mathrm{m}^{-2}\right)$ & \\
\hline & $\left(\mathrm{km}^{2}\right)$ & $(\%)$ & & $\left(\mathrm{kgC} \mathrm{m}^{-2}\right)$ & & $\operatorname{Tg} \mathrm{C}$ \\
\hline Pineland & 3,488 & 15.7 & 3.8 & 2.9 & 2.4 & 13.3 \\
\hline Urban & 2,672 & 12.0 & 3.7 & 3.5 & 1.9 & 9.9 \\
\hline Rangeland & 2,288 & 10.3 & 3.1 & 2.7 & 1.5 & 7.1 \\
\hline Improved Pasture & 1,608 & 7.2 & 4.1 & 3.3 & 2.8 & 6.6 \\
\hline Hardwood Swamp & 1,504 & 6.8 & 9.6 & 9.8 & 5.1 & 14.4 \\
\hline Xeric Upland Forest & 1,457 & 6.5 & 1.9 & 1.5 & 1.0 & 2.8 \\
\hline Freshwater Marsh/Wet Prairie & 1,293 & 5.8 & 6.0 & 5.3 & 3.6 & 7.8 \\
\hline Mixed Wetland Forest & 1,142 & 5.1 & 7.4 & 7.8 & 2.7 & 8.5 \\
\hline Mesic Upland Forest & 1,136 & 5.1 & 3.5 & 2.9 & 1.9 & 4.0 \\
\hline Cypress Swamp & 843 & 3.8 & 9.7 & 9.5 & 4.9 & 8.2 \\
\hline Shrub Swamp & 776 & 3.5 & 5.1 & 5.1 & 5.1 & 4.0 \\
\hline Crop & 751 & 3.4 & 2.2 & 2.1 & 0.7 & 1.7 \\
\hline Citrus & 414 & 1.9 & 2.5 & 2.6 & 0.8 & 1.0 \\
\hline Other Ag. & 189 & 0.9 & - & - & - & - \\
\hline Coastal Upland & 2 & 0.01 & - & - & - & - \\
\hline Other $^{1}$ & 2,706 & 12.1 & - & - & - & - \\
\hline
\end{tabular}
of carbon by land use / land cover classes for dataset 2 .

3841 'Other' designates water, and other land use / land cover classes that were excluded from this analysis. $385{ }^{2}$ (Stys et al., 2004) 
386 Table 3. Relationships between soil organic carbon and land use / land cover classes - Dataset 2

\begin{tabular}{|c|c|c|c|c|c|}
\hline \multicolumn{6}{|l|}{ Land use / Land cover } \\
\hline Hardwood Swamp & & & c & & \\
\hline Cypress Swamp & & & c & $d$ & e \\
\hline Mixed Wetland Forest & & & c & $d$ & \\
\hline Freshwater Marsh/Wet Prairie & a & & c & $d$ & e \\
\hline Shrub Swamp & a & $b$ & c & $d$ & e \\
\hline Urban & a & & & & e \\
\hline Improved Pasture & a & & & $d$ & $\mathrm{e}$ \\
\hline Pineland & a & & & & \\
\hline Mesic Upland Forest & a & $b$ & & & \\
\hline Rangeland & a & $b$ & & & e \\
\hline Citrus & a & $b$ & & & \\
\hline Crop & a & $b$ & & & \\
\hline Xeric Upland Forest & & $\mathrm{b}$ & & & \\
\hline
\end{tabular}

387 Relationship of soil organic carbon at the $95 \%$ significance level according to post hoc multiple

388 comparisons derived from the Kruskal-Wallis test. Soil organic carbon is significantly $(\alpha=0.05)$ different

389 between Land Use / Land Cover classes that do not share a common letter. 
Table A.1. Reclassification of land use / land cover classes

\begin{tabular}{|c|c|}
\hline Original Class & Aggregated Class \\
\hline Coastal Strand & Coastal Upland \\
\hline Sand/Beach & Coastal Upland \\
\hline Xeric Oak Scrub & Xeric Upland forest \\
\hline Sand Pine Scrub & Xeric Upland forest \\
\hline Sandhill & Xeric Upland forest \\
\hline Dry Prairie & Rangeland \\
\hline Mixed Pine-Hardwood Forest & Mesic Upland forest \\
\hline Hardwood Hammocks and Forest & Mesic Upland forest \\
\hline Pinelands & Pinelands \\
\hline Cabbage Palm-Live Oak Hammock & Mesic Upland forest \\
\hline Tropical Hardwood Hammock & Mesic Upland forest \\
\hline Freshwater Marsh and Wet Prairie & Freshwater Marsh and Wet Prairie \\
\hline Sawgrass Marsh & Freshwater Marsh and Wet Prairie \\
\hline Cattail Marsh & Freshwater Marsh and Wet Prairie \\
\hline Shrub Swamp & Shrub Swamp \\
\hline Bay Swamp & Hardwood Swamp \\
\hline Cypress Swamp & Cypress Swamp \\
\hline Cypress/Pine/Cabbage Palm & Cypress Swamp \\
\hline Mixed Wetland Forest & Mixed Wetland Forest \\
\hline Hardwood Swamp & Hardwood Swamp \\
\hline Hydric Hammock & Mixed Wetland Forest \\
\hline Bottomland Hardwood Forest & Mixed Wetland Forest \\
\hline Salt Marsh & To be excluded \\
\hline Mangrove Swamp & To be excluded \\
\hline Scrub Mangrove & To be excluded \\
\hline Tidal Flat & To be excluded \\
\hline Open Water & To be excluded \\
\hline Shrub and Brushland & Rangeland \\
\hline Grassland & Rangeland \\
\hline Bare Soil/Clearcut & To be excluded \\
\hline Improved Pasture & Improved pasture \\
\hline Unimproved Pasture & Rangeland \\
\hline Sugar cane & Crop \\
\hline Citrus & Citrus \\
\hline Row/Field Crops & Crop \\
\hline Other Agriculture & Other Agriculture \\
\hline Exotic Plants & Exotic plants \\
\hline Australian Pine & Exotic plants \\
\hline Melaleuca & Exotic plants \\
\hline Brazilian Pepper & Exotic plants \\
\hline High Impact Urban & Urban \\
\hline Low Impact Urban & Urban \\
\hline Extractive & To be excluded \\
\hline
\end{tabular}

The most detailed level of land cover classes provided by Stys et al. (2004) were aggregated to a coarser 392 level of detail better suited for this projects scale of analysis. 
395 


\section{References}

Allen, L.H., Baker, J.T., Boote, K.J., 1996. The CO2 Fertilization Effect: Higher Carbohydrate Production and Retention as Biomass and Seed Yield. Glob. Clim. Change Agric. Prod. Direct Indirect Eff. Chang. Hydrol. Pedol. Plant Physiol. Process. 65.

Baker, T.R., Phillips, O.L., Malhi, Y., Almeida, S., Arroyo, L., Fiore, A.D., Erwin, T., Higuchi, N., Killeen, T.J., Laurance, S.G., Laurance, W.F., Lewis, S.L., Monteagudo, A., Neill, D.A., Vargas, P.N., Pitman, N.C.A., Silva, J.N.M., Martínez, R.V., 2004. Increasing biomass in Amazonian forest plots. Philos. Trans. R. Soc. Lond. B. Biol. Sci. 359, 353-365. doi:10.1098/rstb.2003.1422

Cairns, M.A., Brown, S., Helmer, E.H., Baumgardner, G.A., 1997. Root biomass allocation in the world's upland forests. Oecologia 111, 1-11. doi:10.1007/s004420050201

Ciais, P., Sabine, C., Bala, G., Bopp, L., Brovkin, V., Canadell, J., Chhabra, A., DeFries, R., Galloway, J., Heimann, M., Jones, C., Le Quere, C., Myneni, R.B., Piao, S., Thornton, P., 2014. Carbon and other biogeochemical cycles, in: Climate Change 2013: The Physical Science Basis. Contribution of Working Group I to the Fifth Assessment Report of the Intergovernmental Panel on Climate Change. Cambridge University Press, pp. 465-570.

Clark, D.A., 2004. Sources or sinks? The responses of tropical forests to current and future climate and atmospheric composition. Philos. Trans. R. Soc. Lond. B. Biol. Sci. 359, 477-491. doi:10.1098/rstb.2003.1426

Conant, R.T., Paustian, K., Elliott, E.T., 2001. Grassland management and conversion into grassland: effects on soil carbon. Ecol. Appl. 11, 343-355. doi:10.1890/10510761(2001)011[0343:GMACIG]2.0.CO;2

Congalton, R.G., 1991. A review of assessing the accuracy of classifications of remotely sensed data. Remote Sens. Environ. 37, 35-46. doi:10.1016/0034-4257(91)90048-B

Davidson, E.A., Ackerman, I.L., 1993. Changes in soil carbon inventories following cultivation of previously untilled soils. Biogeochemistry 20, 161-193. doi:10.1007/BF00000786

Dechert, G., Veldkamp, E., Anas, I., 2004. Is soil degradation unrelated to deforestation? Examining soil parameters of land use systems in upland Central Sulawesi, Indonesia. Plant Soil 265, 197-209. doi:10.1007/s11104-005-0885-8

Del Grosso, S., Parton, W., Stohlgren, T., Zheng, D., Bachelet, D., Prince, S., Hibbard, K., Olson, R., 2008. Global potential net primary production predicted from vegetation class, precipitation, and temperature. Ecology 89, 2117-2126. doi:10.1890/07-0850.1

Eglin, T., Ciais, P., Piao, S.L., Barre, P., Bellassen, V., Cadule, P., Chenu, C., Gasser, T., Koven, C., Reichstein, M., Smith, P., 2010. Historical and future perspectives of global soil carbon response to climate and land-use changes. Tellus B 62, 700-718. doi:10.1111/j.1600-0889.2010.00499.x

Fearnside, P.M., Barbosa, R.I., 1998. Soil carbon changes from conversion of forest to pasture in Brazilian Amazonia. For. Ecol. Manag. 108, 147-166. doi:10.1016/S0378-1127(98)00222-9

Feller, C., Beare, M.H., 1997. Physical control of soil organic matter dynamics in the tropics. Geoderma 79, 69-116. doi:10.1016/S0016-7061(97)00039-6

Fischer, C., Newell, R.G., 2008. Environmental and technology policies for climate mitigation. J. Environ. Econ. Manag. 55, 142-162. doi:10.1016/j.jeem.2007.11.001

Glinka, K.D., 1927. Dokuchaiev's ideas in the development of pedology and cognate sciences. The Academy, Leningrad.

Godfray, H.C.J., Beddington, J.R., Crute, I.R., Haddad, L., Lawrence, D., Muir, J.F., Pretty, J., Robinson, S., Thomas, S.M., Toulmin, C., 2010. Food Security: The Challenge of Feeding 9 Billion People. Science 327, 812-818. doi:10.1126/science.1185383 
Grunwald, S., Harris, W., Comerford, N., Bruland, G., 2011a. Final Report “Rapid Assessment and Modeling of Changes in Soil Carbon Storage and Turnover in a Southern Landscape" USDA-NIFAAFRI grant No. 2007-35107-18368).

Grunwald, S., Thompson, J., Boettinger, J., 2011b. Digital soil mapping and modeling at continental scales: Finding solutions for global issues. Soil Sci. Soc. Am. J. 75, 1201-1213.

Guo, L.B., Gifford, R.M., 2002. Soil carbon stocks and land use change: a meta analysis. Glob. Change Biol. 8, 345-360. doi:10.1046/j.1354-1013.2002.00486.x

Guo, Y., Amundson, R., Gong, P., Yu, Q., 2006. Quantity and Spatial Variability of Soil Carbon in the Conterminous United States. Soil Sci. Soc. Am. J. 70, 590. doi:10.2136/sssaj2005.0162

Heisler, J., Glibert, P.M., Burkholder, J.M., Anderson, D.M., Cochlan, W., Dennison, W.C., Dortch, Q., Gobler, C.J., Heil, C.A., Humphries, E., Lewitus, A., Magnien, R., Marshall, H.G., Sellner, K., Stockwell, D.A., Stoecker, D.K., Suddleson, M., 2008. Eutrophication and harmful algal blooms: A scientific consensus. Harmful Algae, HABs and Eutrophication 8, 3-13. doi:10.1016/j.hal.2008.08.006

Jenny, H., 1941. Factors of Soil Formation: A System of Quantatative Pedology. McGraw - Hill, New york. Johnsen, K.H., Wear, D., Oren, R., Teskey, R.O., Sanchez, F., Will, R., Butnor, J., Markewitz, D., Richter, D., Rials, T., Allen, H.., Seiler, J., Ellsworth, D., Maier, C., Katul, G., Dougherty, P.M., 2001. Meeting Global Policy Commitments: Carbon Sequestration and Southern Pine Forests. J. For. 99, 14-21.

Lal, R., 2014. Abating Climate Change and Feeding the World Through Soil Carbon Sequestration, in: Dent, D. (Ed.), Soil as World Heritage. Springer Netherlands, pp. 443-457.

Lisle, R.J., 2006. Google Earth: a new geological resource. Geol. Today 22, 29-32. doi:10.1111/j.13652451.2006.00546.x

Lugo, A.E., Brown, S., 1993. Management of tropical soils as sinks or sources of atmospheric carbon. Plant Soil 149, 27-41. doi:10.1007/BF00010760

Lumbanraja, J., Syam, T., Nishide, H., 1998. Deterioration of Soil Fertility from Land-use Changes in South Sumatra, Indonesia (1970 to 1990).

Maier, C.A., Albaugh, T.J., Lee Allen, H., Dougherty, P.M., 2004. Respiratory carbon use and carbon storage in mid-rotation loblolly pine (Pinus taeda L.) plantations: the effect of site resources on the stand carbon balance. Glob. Change Biol. 10, 1335-1350. doi:10.1111/j.15298817.2003.00809.x

McBratney, A.B., Mendonça Santos, M.L., Minasny, B., 2003. On digital soil mapping. Geoderma 117, 352. doi:10.1016/S0016-7061(03)00223-4

McBratney, A., Field, D.J., Koch, A., 2014. The dimensions of soil security. Geoderma 213, 203-213. doi:10.1016/j.geoderma.2013.08.013

Minasny, B., Sulaeman, Y., Mcbratney, A.B., 2011. Is soil carbon disappearing? The dynamics of soil organic carbon in Java. Glob. Change Biol. 17, 1917-1924. doi:10.1111/j.13652486.2010.02324.x

National Climatic Data Center, 2011. Climate Data Online (CDO) Data Request Confirmation [WWW Document]. URL http://www.ncdc.noaa.gov/cdo-web/review?mr=t (accessed 7.9.12).

Parton, W.J., Schimel, D.S., Cole, C.V., Ojima, D.S., 1987. Analysis of Factors Controlling Soil Organic Matter Levels in Great Plains Grasslands1. Soil Sci. Soc. Am. J. 51, 1173. doi:10.2136/sssaj1987.03615995005100050015x

Post, W.M., Kwon, K.C., 2000. Soil carbon sequestration and land-use change: processes and potential. Glob. Change Biol. 6, 317-327. doi:10.1046/j.1365-2486.2000.00308.x

Pouyat, R., Groffman, P., Yesilonis, I., Hernandez, L., 2002. Soil carbon pools and fluxes in urban ecosystems. Environ. Pollut. 116, S107-S118. doi:16/S0269-7491(01)00263-9

Prentice, Ic., Farquhar, G., Fasham, M., Goulden, M., Heimann, M., Kheshi, H., Quere, L., Scholes, R., Wallace, D., Archer, D., others, 2001. The carbon cycle and atmospheric carbon dioxide. 
Ross, C.W., Grunwald, S., Myers, D.B., 2013. Spatiotemporal modeling of soil organic carbon stocks across a subtropical region. Sci. Total Environ. 461-462, 149-157. doi:10.1016/j.scitotenv.2013.04.070

Schimel, D.S., 1995. Terrestrial ecosystems and the carbon cycle. Glob. Change Biol. 1, 77-91. doi:10.1111/j.1365-2486.1995.tb00008.x

Shine, K.P., Forster, P.M. de F., 1999. The effect of human activity on radiative forcing of climate change: a review of recent developments. Glob. Planet. Change 20, 205-225. doi:10.1016/S09218181(99)00017-X

Silveira, M., Hanlon, E., Azenha, M., da Silva, H.M., 2012. Carbon Sequestration in Grazing Land Ecosystems [WWW Document]. URL http://edis.ifas.ufl.edu/ss574 (accessed 12.12.14).

Soil Survey Staff, 2008. Soil survey geographic (SSURGO) database.

Stys, B., Kautz, R., Reed, D., Kertis, M., Kawula, R., Keller, C., Davis, A., 2004. Florida vegetation and land cover data derived from 2003 Landsat ETM+ imagery. Fla. Fish Wildl. Conserv. Comm.

United States Geological Survey, 2006. National Elevation Dataset digital elevation model.

U. S. Census Bureau, D.I.S., 2005. 2005 Interim State Population Projections [WWW Document]. URL https://www.census.gov/population/projections/data/state/projectionsagesex.html (accessed 2.24.15).

Vasques, G., Grunwald, S., Comerford, N., Sickman, J., 2010a. Regional modelling of soil carbon at multiple depths within a subtropical watershed. Geoderma 156, 326-336. doi:16/j.geoderma.2010.03.002

Vasques, G., Grunwald, S., Myers, D., 2012. Associations between soil carbon and ecological landscape variables at escalating spatial scales in Florida, USA. Landsc. Ecol. 27, 355-367. doi:10.1007/s10980-011-9702-3

Vasques, G., Grunwald, S., Sickman, J., Comerford, N., 2010b. Upscaling of Dynamic Soil Organic Carbon Pools in a North-Central Florida Watershed. Soil Sci. Soc. Am. J. 74, 870. doi:10.2136/sssaj2009.0242

Vasques, G.M., Grunwald, S., Harris, W.G., 2010. Spectroscopic models of soil organic carbon in Florida, USA. J. Environ. Qual. 39, 923-934.

Watson, R., Noble, I., Bolin, B., Ravindranath, N., Verado, D., Dokken, D., 2000. Land use, land-use change, and forestry. Published for the Intergovernmental Panel on Climate Change [by] Cambridge University Press, Cambridge, UK.

Wear, D.N., Greis, J.G., others, 2002. Southern forest resource assessment-technical report.

Xiong, X., Grunwald, S., Myers, D.B., Kim, J., Harris, W.G., Comerford, N.B., 2014a. Holistic environmental soil-landscape modeling of soil organic carbon. Environ. Model. Softw. 57, 202-215. doi:10.1016/j.envsoft.2014.03.004

Xiong, X., Grunwald, S., Myers, D.B., Ross, C.W., Harris, W.G., Comerford, N.B., 2014b. Interaction effects of climate and land use/land cover change on soil organic carbon sequestration. Sci. Total Environ. 493, 974-982. doi:10.1016/j.scitotenv.2014.06.088 
Figure captions:

Figure 1: The study area displaying the spatial distribution of legacy (Dataset 1 ) and current

532 (Dataset 2) soil survey overlaying the land use / land cover classes adapted from Stys et al. 2004.

Figure 2. Soil suborders of the region adapted from Soil Survey Staff, 2008

535

Figure 3: Variability of soil organic carbon $(0-20 \mathrm{~cm})$ by soil sub-order - Dataset 1 . The horizontal

537 line in the box represents median SOC, while the "top" and "bottom" of the box represent the upper 538 and lower quartiles of the data, respectively. The "whiskers" represent the highest and lowest values 539 that are within 1.5 times the inter quartile range, while dots represent extreme values.

540

541

Figure 4: Variability of current soil organic carbon $(0-20 \mathrm{~cm})$ by soil sub-order - Dataset 2

542

Figure 5. Variability of soil organic carbon $(0-20 \mathrm{~cm})$ by land use / land cover class (Dataset 2).

544

Figure 6. Soil organic carbon change per year according to land use / land cover class using

546 paired and un-paired (collocated) samples from Datasets 1 and 2

547

548

Figure 7. Soil organic carbon change per year for each land use / land cover class using paired-

549 comparisons from datasets 1 and 2 


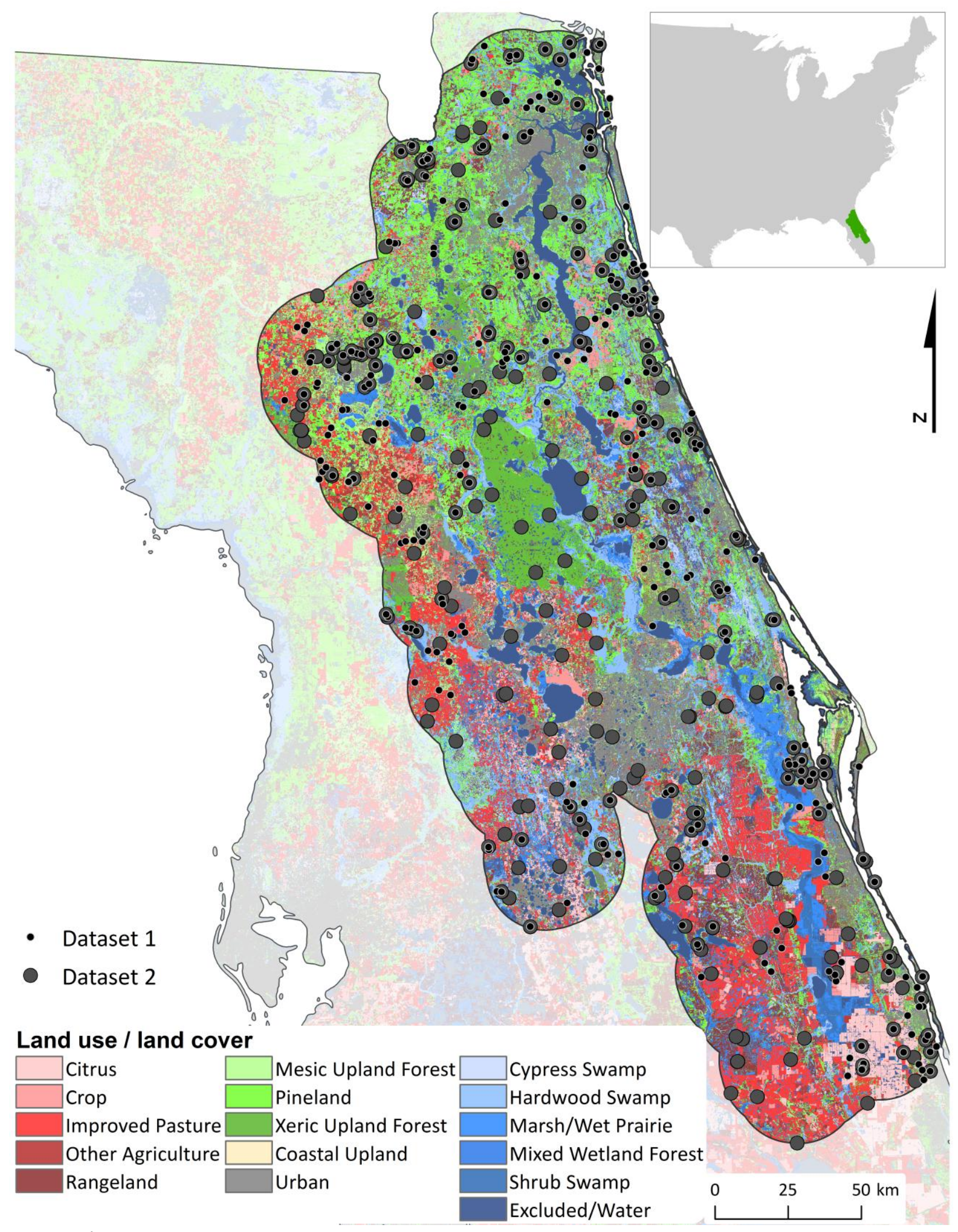

Figure 1 


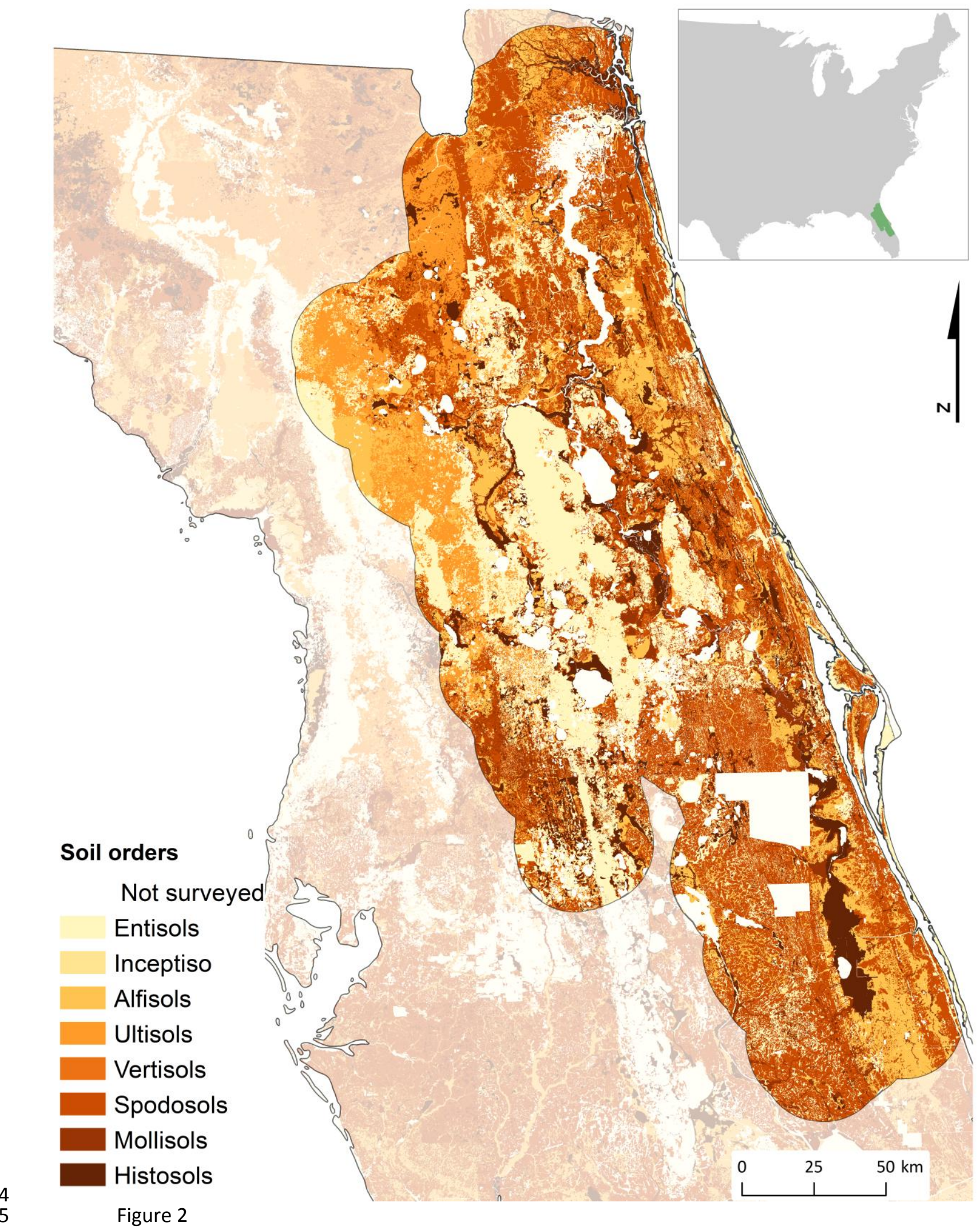




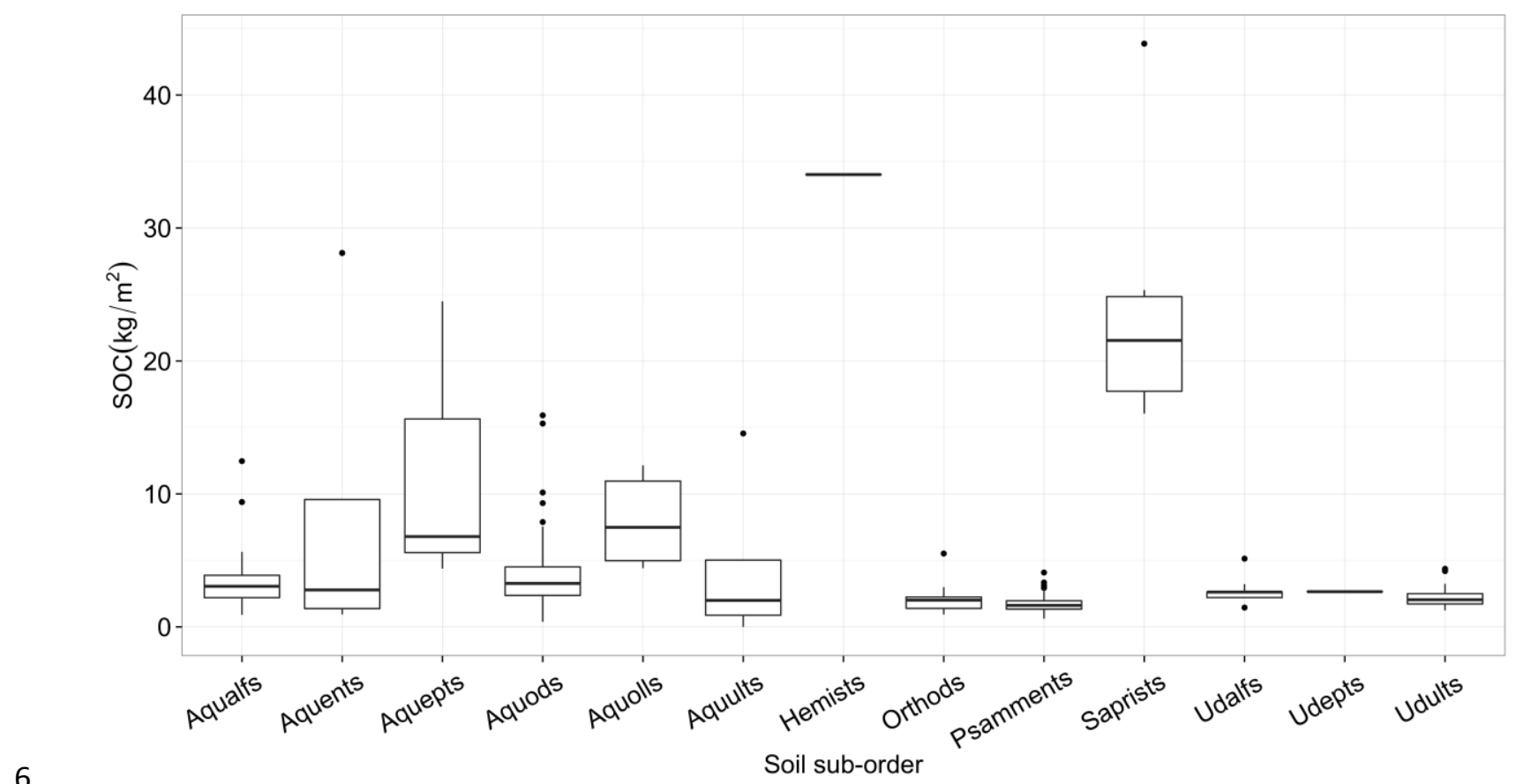

Figure 3 


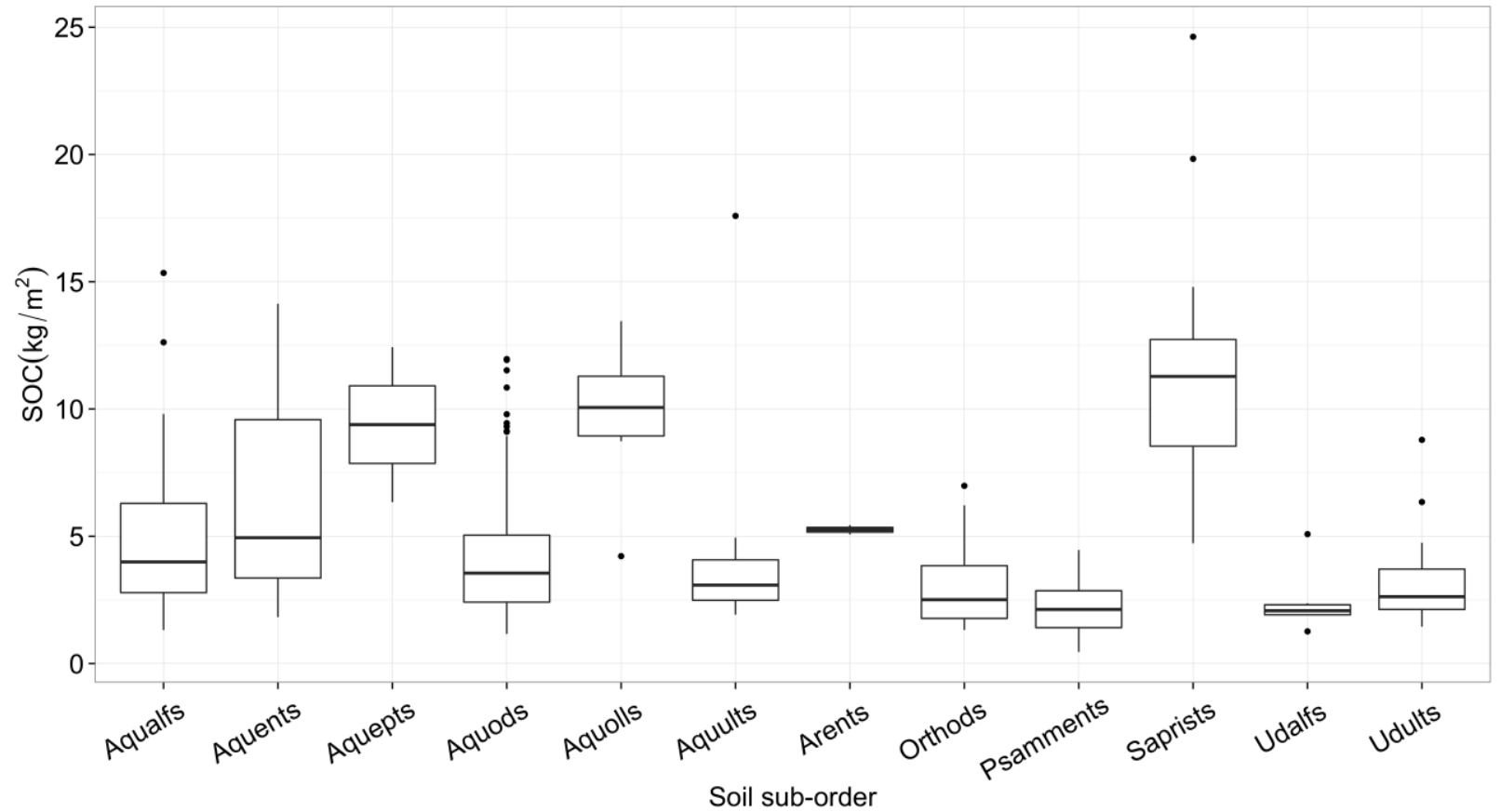

Figure 4 


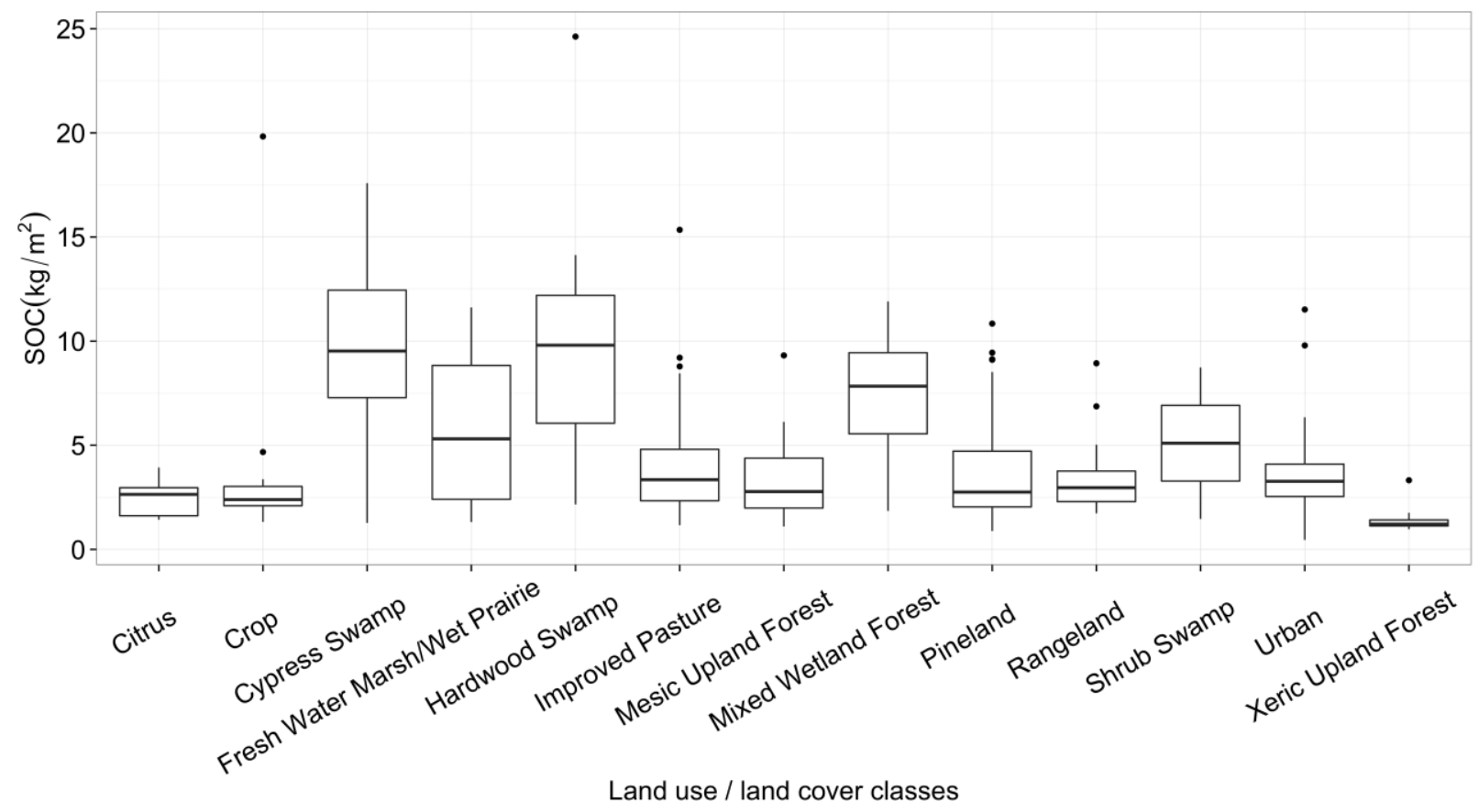

Figure 5 
12

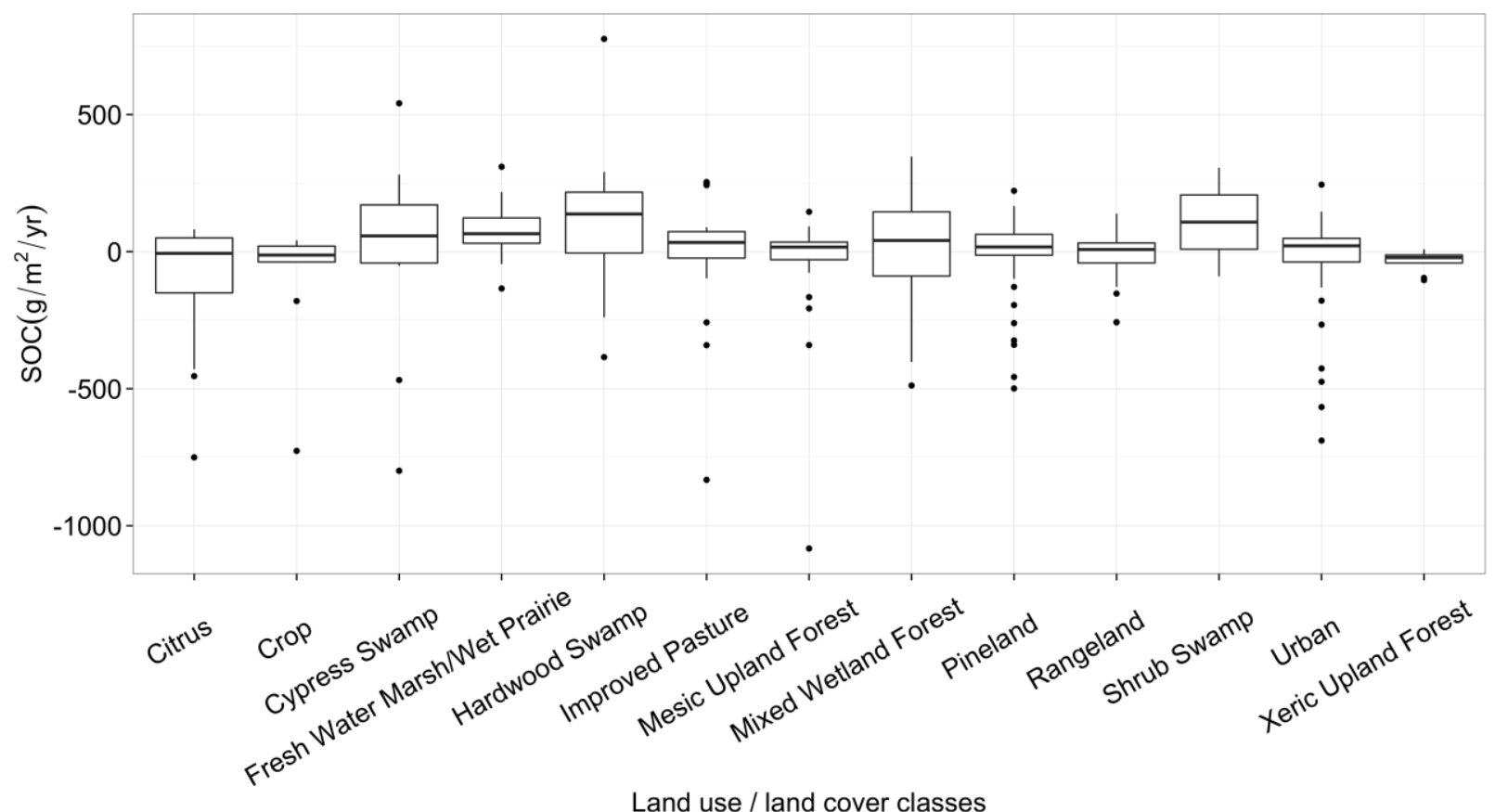

Figure 6 


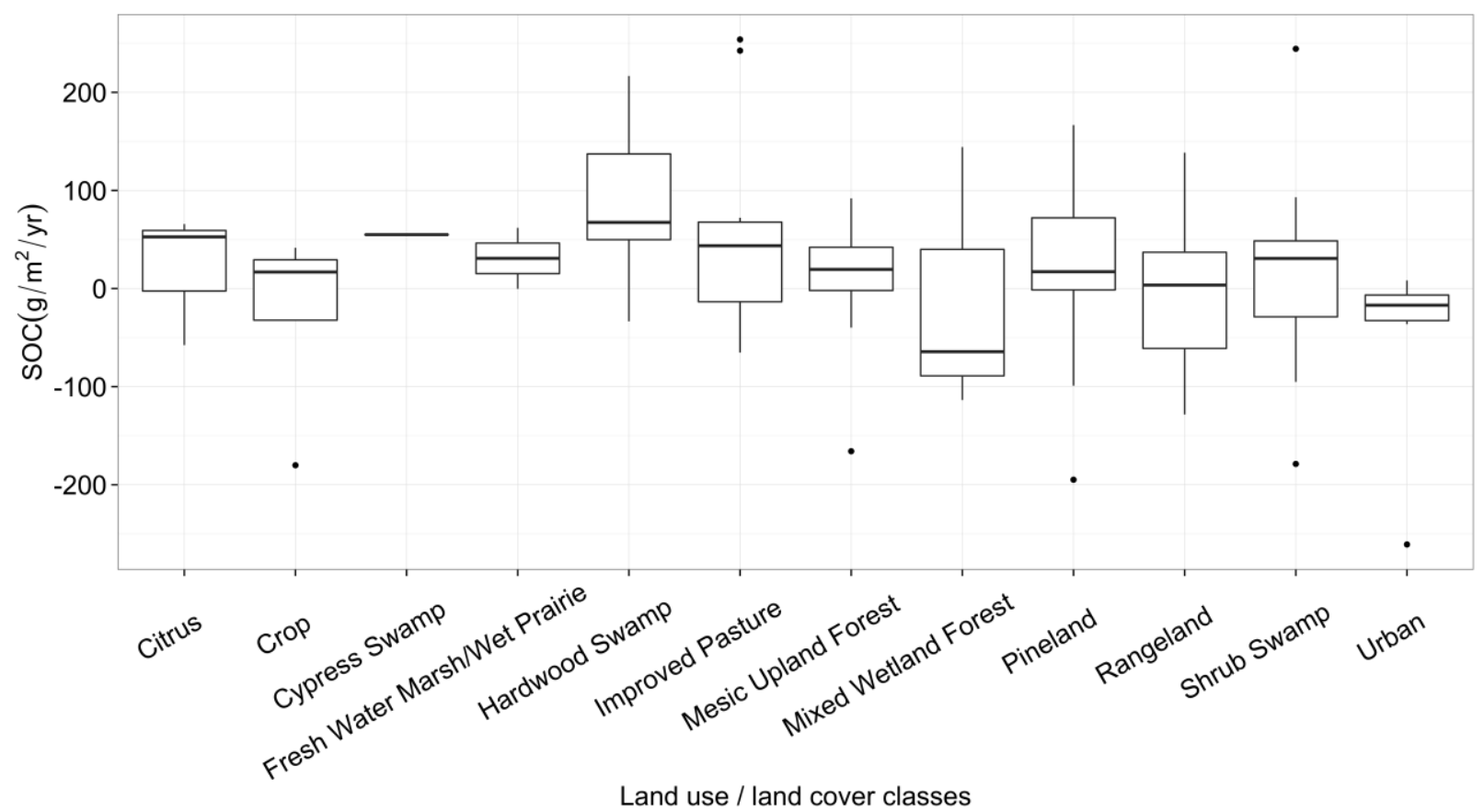

Figure 7 